\title{
INVESTIGATION OF THE SYNERGISM OF AIR POLLUTION AND RUGGLE POLLENE LOAD
}

\author{
Pölös Endre ${ }^{1 *}$, Palkovics András ${ }^{1}$, Szabó Csaba ${ }^{1}$, Tatjana Duric ${ }^{2}$, Hóman Zoltán ${ }^{1}$ Tóth Horgosi \\ Péter ${ }^{1}$ \\ ${ }^{1}$ Department of Horticulture, Faculty of Horticulture and Rural Development, János Neumann University, \\ Hungary \\ ${ }^{2}$ Autonomous Province of Vojvodina, Republic of Serbia, Újvidék \\ https://doi.org/10.47833/2020.2.AGR.015
}

\section{Keywords: \\ ragweed \\ allergens \\ pollen \\ ozone \\ air pollution}

\section{Article history:}

Received 10 Feb 2020

Revised 13 March 2020

Accepted 20 March 2020

\begin{abstract}
In summer, high atmospheric ozone levels not only burden the respiratory tract (mucous membrane irritation, respiratory distress, respiratory tract inflammation), but even the allergen content of plants can be increased. Ozone in the vicinity of the soil is formed from primary pollutants by photochemical means. Primary pollutants include nitrogen oxides, volatile organic compounds and solvents from vehicle exhaust fumes. Solar radiation generates ozone $\left(\mathrm{O}_{3}\right)$ from nitrogen oxides. High levels of ozone can greatly aggravate the symptoms of people with pollen allergy.
\end{abstract}

\section{Introduction}

In summer, high levels of atmospheric ozone not only burden the respiratory tract (mucous membrane irritation, respiratory distress, respiratory tract inflammation), but even the allergen content of plants can be increased according to research carried out by Vienna researchers [2]. Ozone in the vicinity of the soil is formed from primary pollutants by photochemical means. Primary pollutants include nitrogen oxides, volatile organic compounds and solvents from vehicle exhaust fumes. Solar radiation generates ozone $\left(\mathrm{O}_{3}\right)$ from nitrogen oxides. High levels of ozone can greatly exacerbate the symptoms of people with pollen allergy [1].

\section{Method}

In July 2018. and October 10, 2018 only concentrations of airborne ozone $\left(\mathrm{O}_{3}\right)$ and particulate matter (PM10) in the $10 \mu \mathrm{m}$ range were available in Kecskemét measuring station, since other air pollutants $\left(\mathrm{SO}_{2}, \mathrm{NO}_{2}, \mathrm{CO}, \mathrm{NOx}, \mathrm{NO}\right.$, etc.) have concentrations below the limit values. The health limit values for ozone and particulate matter are given in Table 1.

Table 1.: Health limit values for air pollutants

\begin{tabular}{|l|l|}
\hline \multicolumn{1}{|c|}{ Air pollutant } & \multicolumn{1}{c|}{ Health limit $\left(\mu \mathrm{g} / \mathrm{m}^{3}\right)$} \\
\hline Ozone $\left(\mathrm{O}_{3}\right)$ & 120 \\
\hline $\begin{array}{l}\text { suspended particulate matter }(\mathrm{PM} 10)- \\
\text { small particle size }\end{array}$ & 50 \\
\hline sulfur dioxide $\left(\mathrm{SO}_{2)}\right.$ & 250 \\
\hline
\end{tabular}

\footnotetext{
* Corresponding author. E-mail address: polos.endre@kvk.uni-neumann.hu
} 


\begin{tabular}{|l|l|}
\hline nitrogen dioxide $\left(\mathrm{NO}_{2}\right)$ & 100 \\
\hline carbon monoxide $(\mathrm{CO})$ & 10000 \\
\hline
\end{tabular}

In July 2018 only ozone $\left(\mathrm{O}_{3}\right)$ and particulate matter (PM10) were measured (Figure 1). In July, ozone was highest at $7\left(124.4 \mu \mathrm{g} / \mathrm{m}^{3}\right)$ and $25\left(120.1 \mu \mathrm{g} / \mathrm{m}^{3}\right)$ (at which point the health limit was exceeded) and $22\left(6.8 \mu \mathrm{g} / \mathrm{m}^{3}\right)$. was the lowest concentration. On the 25th, the particulate matter reached its highest level $\left(57 \mu \mathrm{g} / \mathrm{m}^{3}\right)$, already above the health limit, and on the 10th it was the lowest $\left(2 \mu \mathrm{g} / \mathrm{m}^{3}\right)$.

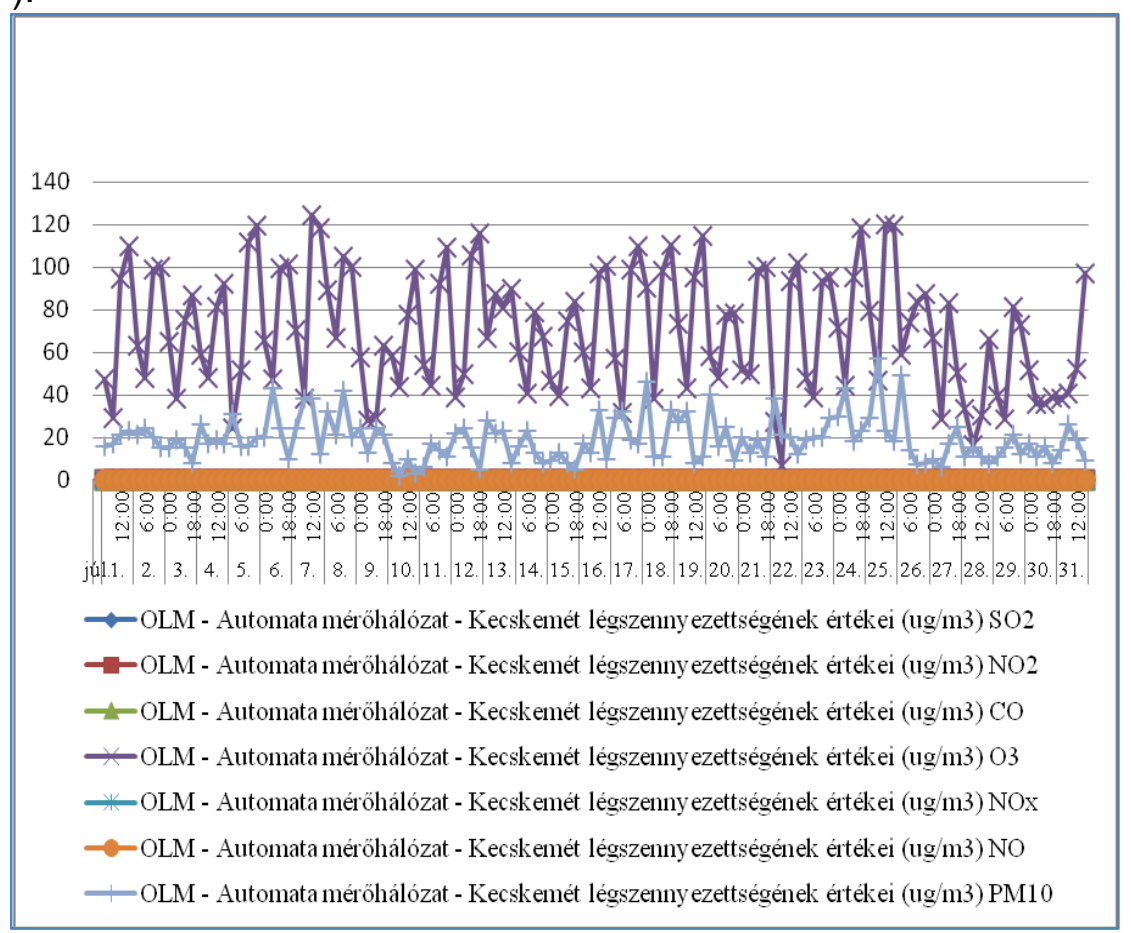

Figure 1: Air pollution data in Kecskemét, July 2018 Source: OLM data (2018) - own edited

In August 2018, ozone $\left(\mathrm{O}_{3}\right)$ concentrations peaked at $13\left(133.5 \mu \mathrm{g} / \mathrm{m}^{3}\right)$ and lowest $(0.5 \mu \mathrm{g} /$ $\left.\mathrm{m}^{3}\right)$ at 24 and 29 (Figure 2).

The health limit value $(120 \mu \mathrm{g} / \mathrm{m} 3)$ was exceeded several times by ozone air pollution on 13 August $(133.5 \mu \mathrm{g} / \mathrm{m} 3), 15$ August $\left(130.1 \mu \mathrm{g} / \mathrm{m}^{3}\right), 16$ August $\left(126 \mu \mathrm{g} / \mathrm{m}^{3}\right)$ and on August $31(127.4$ $\left.\mu \mathrm{g} / \mathrm{m}^{3}\right)$. No data was available on August 30 from 6:00 to 18:00 and on 31 August from 0:00 to 6:00.

In August, suspended particulate matter (PM10) was at its highest level $\left(85 \mu \mathrm{g} / \mathrm{m}^{3}\right)$ on day 29 and was lowest in air $\left(19 \mu \mathrm{g} / \mathrm{m}^{3}\right)$ (Figure 2).

Exposure limit values $\left(50 \mu \mathrm{g} / \mathrm{m}^{3}\right)$ were exceeded on 12 August $\left(55 \mu \mathrm{g} / \mathrm{m}^{3}\right), 13$ August $(51$ $\left.\mu \mathrm{g} / \mathrm{m}^{3}\right)$, 14 August $\left(59 \mu \mathrm{g} / \mathrm{m}^{3}\right), 16$ August $\left(52 \mu \mathrm{g} / \mathrm{m}^{3}\right)$, August $17\left(53 \mu \mathrm{g} / \mathrm{m}^{3}\right)$, August $28(50 \mu \mathrm{g} /$ $\mathrm{m}^{3}$ and $\left.62 \mu \mathrm{g} / \mathrm{m}^{3}\right)$, and August $29\left(85 \mu \mathrm{g} / \mathrm{m}^{3}\right.$ and $\left.53 \mu \mathrm{g} / \mathrm{m}^{3}\right)$. 


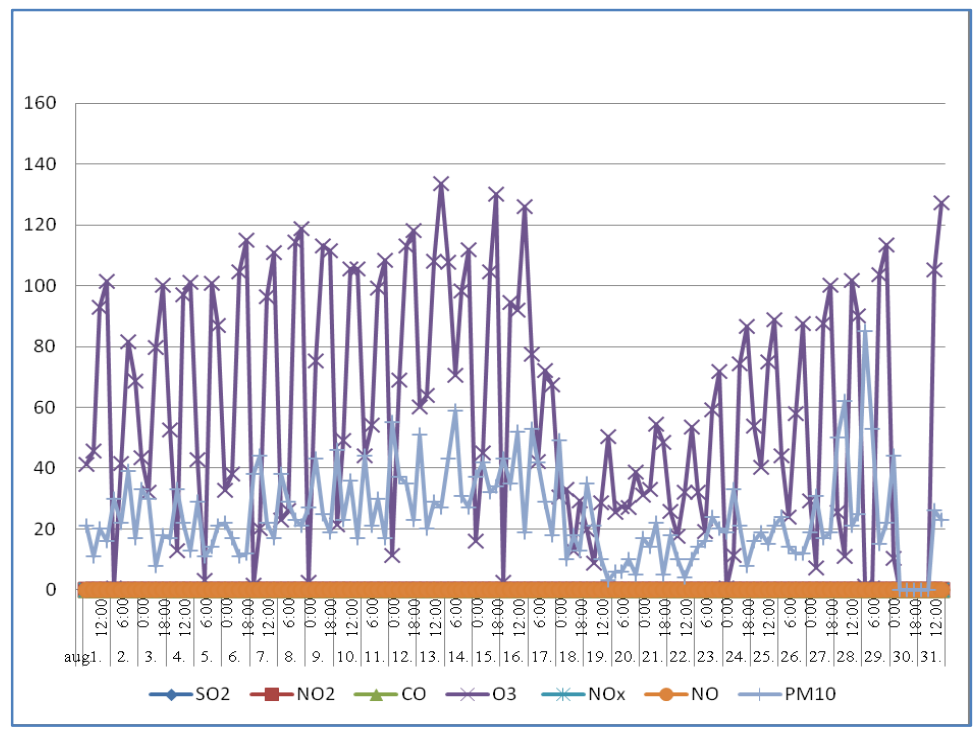

Figure 2: Air pollution data in Kecskemét in August 2018 Source: OLM Data (2018) - self-edited

By September, the ozone concentration was no longer above the health limit $\left(120 \mu \mathrm{g} / \mathrm{m}^{3}\right)$, reaching its highest level $\left(109.9 \mu \mathrm{g} / \mathrm{m}^{3}\right)$ on 1 and the lowest on $26\left(2.9 \mu \mathrm{g} / \mathrm{m}^{3}\right)(3$. figure). Particulate matter exceeded the health limit $\left(50 \mu \mathrm{g} / \mathrm{m}^{3}\right)$ on several occasions this month: on 1 September $\left(59 \mu \mathrm{g} / \mathrm{m}^{3}\right)$, on 18 September $\left(53 \mu \mathrm{g} / \mathrm{m}^{3}\right)$ and on 25 September $\left(51 \mu \mathrm{g} / \mathrm{m}^{3}\right)$. The highest concentration was observed on September $1\left(59 \mu \mathrm{g} / \mathrm{m}^{3}\right)$, and the lowest on September 30 $\left(2 \mu \mathrm{g} / \mathrm{m}^{3}\right)$ (Figure 3).

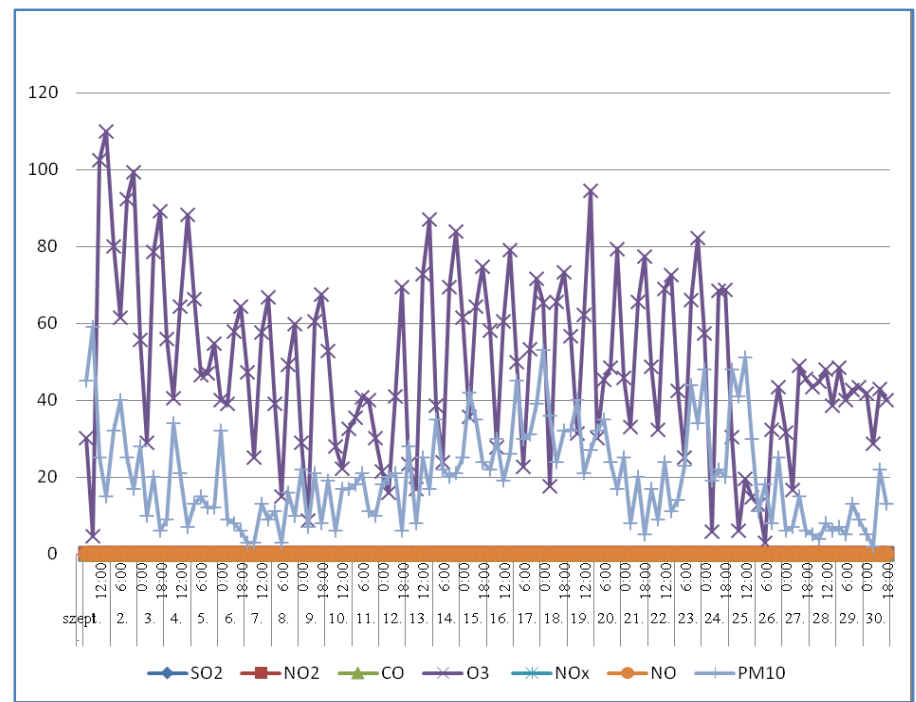

Figure 3: Air pollution data in Kecskemét in September 2018 Source: OLM Data (2018) - self-edited

In October, ozone concentrations were well below the health limit $\left(120 \mu \mathrm{g} / \mathrm{m}^{3}\right)$. It was highest on October $4\left(66.4 \mu \mathrm{g} / \mathrm{m}^{3}\right)$ and lowest on October $30\left(0.1 \mu \mathrm{g} / \mathrm{m}^{3}\right)$ (Figure 5). Ozone air pollution data were not available on 22 October (0:00 and 6:00), 23 October (6:00), 24 October (6:00), on October 30 (6:00) and October 31 (0: 00-6: 00). 

months.

Concentration of particulate matter (PM10) reached its highest level in October of the 4

Health limit values $\left(50 \mu \mathrm{g} / \mathrm{m}^{3}\right)$ were exceeded on October $22\left(58\right.$ and $\left.53 \mu \mathrm{g} / \mathrm{m}^{3}\right)$, on October $26\left(52 \mu \mathrm{g} / \mathrm{m}^{3}\right)$, on 29 October $\left(51 \mu \mathrm{g} / \mathrm{m}^{3}\right)$, and on 30 October $\left(51 \mu \mathrm{g} / \mathrm{m}^{3}\right.$ and $\left.89 \mu \mathrm{g} / \mathrm{m}^{3}\right)$ and 31 October $\left(75 \mu \mathrm{g} / \mathrm{m}^{3}, 94 \mu \mathrm{g} / \mathrm{m}^{3}\right.$ and $65 \mu \mathrm{g} / \mathrm{m}^{3}$, respectively) (Figure 4$)$.

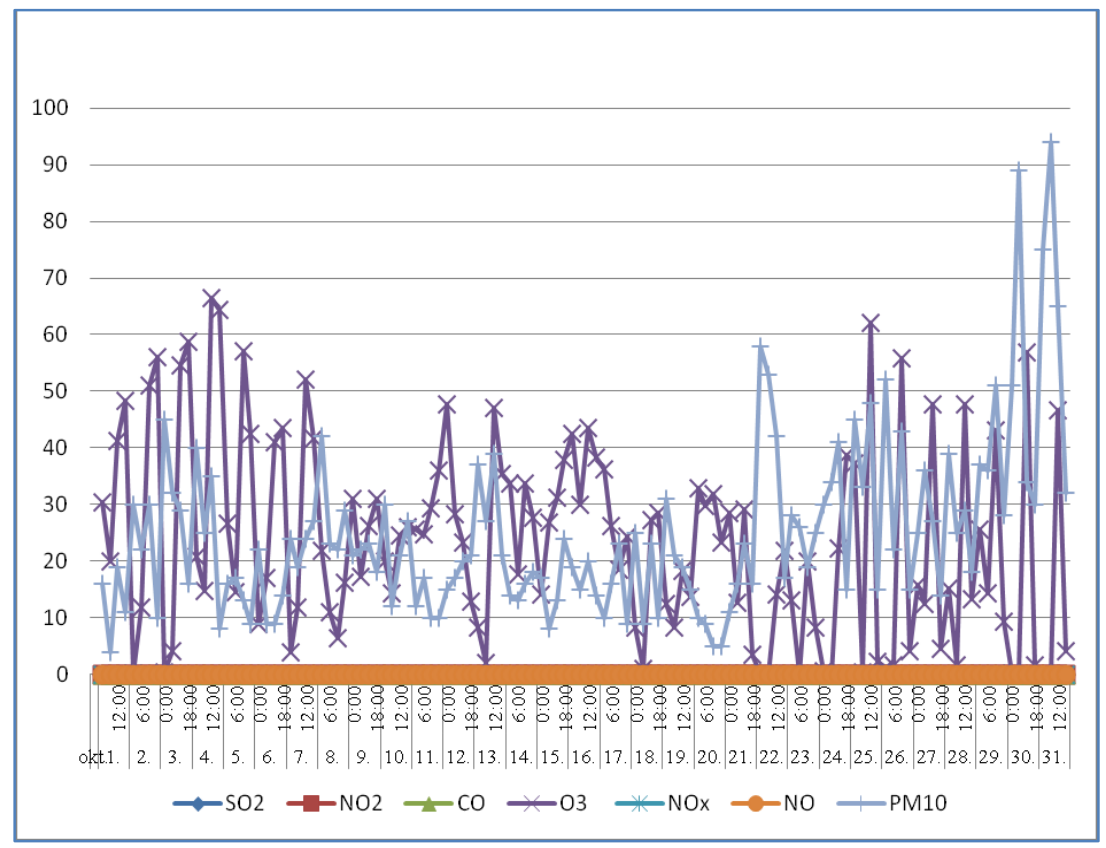

Figure 4: Air pollution data in Kecskemét, October 2018 Source: OLM Data (2018) - self-edited

\section{Results}

\subsection{Comparison of ragweed pollen data and air pollution measurement data from The National Public Health and Medical Officer Service in Kecskemét, 2018}

Ragweed pollen levels reached a very high level from week 32 to week 38 (08/08/2018 $18 / 09 / 2018)$, at which time allergy symptoms were severe. The concentrations of ozone $\left(\mathrm{O}_{3}\right)$ and 10 $\mu \mathrm{m}$ fly-dust (PM10) were also variable during this time interval.

Ozone levels increased gradually between August 24 and September 1, followed by a fall between September 2 and September 11. Subsequently, between 13 September and 19 September, ozone air pollution levels increased again.

The concentration values of the particulate matter showed great fluctuation in the period from August 24 to September 19. PM10 levels increased from August 24 to August 29, but a decrease was observed as of mid-day 29. It rose again at 0:00 on August 30, then no data was available from 6:00 am to 6:00 am on August 31, since it was well below the limit. From August 31, there was an increase again until mid-September, when the concentration decreased again, and this fluctuation continued until 19.

Ozone concentrations peaked in August, exceeding several times the health limit $(120 \mu \mathrm{g} /$ m3). However, the concentration of airborne dust showed very high values in October. 


\subsection{Number of patients with respiratory allergy in Kecskemét}

Table 1.: Number of patients with respiratory allergy in Kecskemét (2018)

\begin{tabular}{|l|l|}
\hline $\begin{array}{l}\text { Total number of registered respiratory } \\
\text { allergy sufferers (persons) in } 2018\end{array}$ & 5493 \\
\hline $\begin{array}{l}\text { Total number of patients suffering from } \\
\text { pollen allergy in } 2018 \text { (persons) }\end{array}$ & 4033 \\
\hline $\begin{array}{l}\text { Number of pollen allergies registered in } \\
2017 \text { (persons) }\end{array}$ & 3811 \\
\hline $\begin{array}{l}\text { Number of newer pollen allergies registered } \\
\text { in } 2018 \text { (persons) }\end{array}$ & 222 \\
\hline
\end{tabular}

(Source: Kecskemét Lung Care Institute data (2018) - self-edited)

Table 2 shows that in Kecskemét the Lung Care Institute registered a total of 5,493 patients with respiratory allergies in 2018 , accounting for nearly $5 \%$ of the city's population $(111,836$ as of January 1,2018 ). Of the 5,493 patients with respiratory allergy, a total of 4,033 were allergic to pollen, accounting for $3.6 \%$ of the population of Kecskemét $(111,836)$.

Nearly $80 \%$ of the 4,033 registered patients $(3,220)$ are allergic to ragweed pollen.

\section{Discussion}

Researches from Vienna confirmed that plants with high levels of ozone, including ragweed, have increased allergenic content. The main reason for this is that the protein extract of plant species heavily exposed to ozone reacts strongly with Immunglobulin-E antibodies, which play an important role in the development of allergies. Nitrogen oxides (NOx) scrub the outer sheath of ragweed pollen, under which the released claws irritate the airway.

Increasing atmospheric $\mathrm{CO}_{2}$ concentration and global warming are also responsible for the high pollen production of ragweed.

Concentrated dust (PM10) concentrations exceeded the health limit $(50 \mu \mathrm{g} / \mathrm{m} 3) 13$ times during high and very high ragweed pollen production (03/08/2018 - 18/09/2018), which is very dangerous because even at the lowest concentration can be very harmful.

\section{Conclusion}

The main emission sources of particulate matter are exhaust gas and coal combustion. As a result, the proportion of respiratory diseases (asthma and chronic bronchitis) is increased, including pollen allergy.

In 2018 , nearly $80 \%(3,220)$ of the 4,033 patients with pollen allergies registered at the Kecskemét Lung Care Institute also developed allergic symptoms to ragweed pollen. Compared to 2017, the number of registered pollen allergies increased by 222 persons.

\section{Acknowledgment}

This research is supported by EFOP-3.6.2-16-2016-00006 "The development and enhancement of the research potential at John von Neumann University" project. The Project is supported by the Hungarian Government and co-financed by the European Social Fund.

\section{References}

[1] Juhász M. (2011): Bonyodalmak a parlagfü körül. Gakorlati allergológia. Amega, Vol. 18. No.4. pp.25-32

[2] Harsányi. E. (2009): Parlagfü és allergia Növényvédelem Vol.45. No.8. pp. 454-458 